\title{
Dom Quixote de La Mancha, de Miguel de Cervantes, para leitores juvenis
}

\author{
Jeanne Sousa da Silva* \\ Diógenes Buenos Aires de Carvalho**
}

\section{Resumo}

Este artigo aborda a tradução adaptada de Dom Quixote de La Mancha, de Miguel de Cervantes, realizada por Ferreira Gullar. O estudo centra-se na análise das estratégias utilizadas pelo adaptador para tornar o clássico cervantino mais próximo do jovem leitor. Dessa forma, foi imprescindível o aporte teórico da estética da recepção, de Jauss (1994), visto que a modalidade de texto em estudo configura-se com uma forma explícita de recepção. Para compreender de que maneira o adaptador maneja o texto com vistas a concretizar sua recepção, foi necessário trilhar pelos estudos de Zilberman (1989) por apresentar os quatro ângulos da adaptação propostos por Göte Klimberg. Os estudos de Carvalho (2006), Monteiro (2010), Amorim (2005), também foram fundamentais por apontarem para a iminência de uma teoria da adaptação.

Palavras-chave: Adaptação literária. Dom Quixote. Estética da Recepção

\section{Introdução}

Este artigo analisa o processo de adaptação de Ferreira Gullar em Dom Quixote de La Macha, de Miguel de Cervantes, buscando verificar quais foram suas estratégias adaptativas, visando atingir seu público-leitor; analisar a recepção e os horizontes de expectativa do texto adaptado, tendo como base os conceitos básicos da Estética da Recepção, de Hans Robert Jauss (1994), exatamen-

\footnotetext{
Mestre em Letras (Uespi). Docente da Secretaria Municipal de Educação do Maranhão, Secretaria Municipal de São Luís (MA), atuou como profa. substituta da Universidade Estadual do Maranhão. E-mail: jeanness01@gmail.com

** Doutor em Letras (PUCRS). Docente da Universidade Estadual do Piauí (UESPI) e atua na Graduação e no Mestrado em Letras. Autor dos livros As crianças contam as histórias: os horizontes dos leitores de diferentes classes sociais, e A adaptação literária para crianças e jovens: Robinson Crusoé no Brasil. E-mail: dbuenosaires@uol.com.br
}

Data de submissão: mar. 2015 - Data de aceite: maio 2015 http://dx.doi.org/10.5335/rdes.v11i1.5055 
te pelo enfoque dado ao leitor no processo de recepção de uma obra literária.

Dessa forma, dividiu-se o estudo em dois tópicos. No primeiro, analisou-se de que modo Gullar realiza a adaptação da forma, isto é, as estratégias usadas pelo adaptador para reintroduzir o clássico cervantino, tornando-o mais acessível aos jovens leitores. Nessa análise, buscou-se destacar a adaptação realizada nos elementos da narrativa, centrando-se sobretudo no percurso narrativo (enredo) e na composição das personagens (Dom Quixote e Sancho), exatamente por serem esses os elementos que sustentam a adaptação de Gullar. No segundo tópico, a análise voltou-se para os outros três ângulos propostos por Klimberg, a adaptação do assunto, do estilo e do meio. Em cada um deles buscou-se destacar os manejos realizados por Gullar para viabilizar a recepção do clássico cervantino, e assim tornar sua forma e seu conteúdo mais atrativos ao jovem leitor.

Reconhecendo o texto adaptado como uma das formas de recepção da obra literária, esta pesquisa, visa evidenciá-lo, como uma das possibilidades de aproximar o leitor contemporâneo da obra fonte, uma vez que esse se configura como um gênero emancipador de leitores, diminuindo o abismo estético existente entre o leitor e a obra original.

\section{A estética de Dom \\ Quixote: estratégias narrativas e o diálogo com o leitor juvenil}

Ao aceitar o desafio de traduzir a obra em questão para o público juvenil, Gullar trata de relê-la, pois segundo ele "ler para traduzir é diferente de ler por ler, claro"1, principalmente em se tratando de uma tradução direcionada a um público "menos disposto a encarar uma obra bastante volumosa, escrita em estilo e linguagem de outra época" (CERVANTES, 2005, nota do tradutor). Levando em consideração o perfil desse público-leitor, o escritor faz, conforme sua própria classificação, uma tradução adaptada, isto é, uma tradução que não traduz ipsis verbis o original de Cervantes, mas se vale de procedimentos adaptativos para aproximar o texto-fonte do contexto atual.

Essa forma de classificar o texto pode estar, segundo Amorim (2005, p. 120) relacionada à noção de "licença" que o termo adaptação confere ao adaptador para modificar o texto-fonte, já que o termo tradução é entendido como um procedimento menos flexível, sobretudo em se tratando das transformações estruturais. Desse modo, ao unir os termos, Gullar justifica as adequações realizadas em seu trabalho, conferindo-lhe dois aspectos: de preservar a obra fonte, mantendo-se fiel ao autor e à sua essência estética e de atualizar e simplificar tal obra às novas exigências sociais e culturais em que 
estão inseridos os leitores. Diante dessas considerações, porém, vale citar Pereira ao lembrar que:

Quando falamos em simplificação da linguagem, não falamos em banalização. Um texto pode manter-se vigoroso com palavras que pertencem ao vocabulário comum, dispensando as eruditas ou utilizando-as apenas num contexto que as exija (2005, p. 19).

Neste ponto da pesquisa o foco recai sobre a análise das estratégias literárias utilizadas por Gullar na composição de sua narrativa, na qual, serão consideradas as anotações de Zilberman (1989) sobre o ângulo da adaptação da forma proposto por Göte Klimberg. Desse modo, verificar-se-á de que maneira esse maneja os elementos da narrativa-fonte com vistas a possibilitar ao seu público-alvo o primeiro contato com Dom Quixote de La Mancha, de Miguel de Cervantes.

Para tanto, durante a análise, utilizou-se como parâmetro a obra fonte, que no caso trata-se de uma edição espanhola, da editora Debolsillo, ano 2013, sob a responsabilidade de Florencio Sevilla Arroyo. Desse modo, sempre que necessário, foram transcritos alguns trechos de ambas as obras, para melhor ilustrar os procedimentos tradutórios e adaptativos usados por Gullar, e assim compreender o propósito deles.

O clássico cervantino é estruturalmente dividido em três partes: a primeira saída de Dom Quixote de sua terra em busca de aventuras (narrativa em forma de novela curta); a segunda é desenvolvida graças à incorporação de Sancho Pança, do manuscrito árabe e da invenção de Cide Hamete. E por fim, a terceira saída (que está na segunda parte do livro) que, consoante Arroyo:

[...] se fundamenta, ante todo, en el hecho de que la primera haya sido ya publicada. De resultas, el conjunto queda perfectamente homogeneizado y, asombrosamente, Alonso Quijano el Bueno acaba muriendo al final (2013, p. 30). ${ }^{2}$

Para manter o equilíbrio entre preservar e transformar, Gullar tanto conserva a linearidade e a lógica interna do texto de Cervantes, como subtrai dessa os trechos que considera a mais na estrutura, exatamente por acreditar que seriam obstáculos à leitura. Assim, dispensa do texto-fonte, qualquer outra informação que quebre o ritmo de sua narrativa e prejudique o diálogo com seu público-alvo. $\mathrm{O}$ adaptador, portanto, centra sua descrição inicial na ambientação do espaço físico e familiar habitado pelo velho fidalgo.

Num lugar da Mancha, cujo nome não desejo lembrar, vivia, não faz muito tempo, um desses fidalgos de lança no cabide, escudo antiquado, cavalo magro e galgo corredor. Morava numa fazenda com uma ama que passava dos 40, uma sobrinha que não chegava aos 20 e um criado que tanto selava o cavalo como empunhava a podadeira (CERVANTES, 2005, p. 11, grifo nosso).

Ainda na parte expositiva do enredo, Gullar descreve de que forma Dom Quixote entra em contato com os livros de cavalaria e de como essas leituras o levaram a loucura. Na descrição, o texto centra-se nos trechos que envolvem Dom Quixote e os livros e suprime as referências a outros autores e histórias de cavalaria, como a Feliciano de Silva e Amadís de Gaula. 
Obra fonte

Es pues, de saber que este sobredicho hidalgo, los ratos que estaba ocioso, que eran lo más del año, se daba a leer libros de caballerías, con tanta afición y gusto, que olvidó casi de todo punto el ejercicio de la caza y aun la administración de su hacienda. Y llegó a tanto su curiosidad y desatino en esto, que vendió muchas hanegas de tierra de sembradura para comprar libros de caballería en que leer, y así, llevó a su casa todos cuantos pudo haber dellos; y de todos, ningunos le parecían tan bien como los que compuso el famoso Feliciano Silva, porque la claridad de su prosa y aquellas entricadas razones suyas le parecían de perlas, y más cuando llegaba a leer aquellos requiebros y cartas de desafíos, donde en muchas partes hablaba escrito: La razón de la sinrazón que a mi razón se hace, de tal manera mi razón enflaquece, con que con razón me quejo de la vuestra fermosura. Y también cuando leía: los altos cielos que de vuestra divindad divinamente con las estrellas os fortifican y os hacen merecedora del merecimiento que merece la vuestra grandeza. Con estas razones perdía el pobre caballero el juicio [...] (CERVANTES, 2013 , p. 70 , grifo nosso).
Obra adaptada

O importante é saber que nos momentos de ócio - que eram muitos - o referido fidalgo se punha a ler livros de cavalaria com tanto empenho e prazer, que quase se esquecia por completo da caça e da administração da fazenda; e tanta era sua paixão por essas histórias que chegou a vender partes de sua terra para comprar livros de cavalaria, levando para casa todos os que pôde comprar. Encantado com a clareza da prosa e os volteios do estilo, o pobre cavaleiro foi perdendo o juízo. (CERVANTES, 2005, p. 11, grifo nosso).
No trecho excluído pelo adaptador, Cervantes faz referência à clareza da prosa de Feliciano e para exemplificá-la, transcreve um fragmento, em que apresenta um texto redundante e confuso. O paradoxo criado revela a ironia construída para, dentre outras intenções estéticas, satirizar a novela de cavalaria, que tinha sido popular na Europa, mas que, em sua época, enfrentava a decadência, sobretudo pelo exagero dos rodeios e excessos na linguagem.

Para os leitores do século XVII, a referência de Cervantes a essas novelas de cavalaria é justificável, já que o sistema de referência histórico-literário vigente, bem como a familiaridade desse leitor com as convenções do gênero fazem com 
que esse acione seu repertório de leituras e reconheça no estilo e na forma do texto de Cervantes, traços de uma estética que lhe é familiar. A ironia, desse modo, é empregada como uma estratégia do autor para confrontar esse horizonte de leitura, levando o receptor a ampliar e reconstruir sua percepção estética.

Diante das novas expectativas do leitor do século XXI, e levando em consideração a distância estética entre as obras, Gullar retira os elementos que inviabilizam a fusão dos horizontes, compreendendo que a manutenção das histórias intercaladas não seria atraente, dada a necessidade de situar o leitor por meio de constantes notas esclarecedoras. Por isso, preserva os trechos-chave, nos quais estão contidos os "sinais visíveis e invisíveis" que preparam o público para entrar no mundo ficcional em que Dom Quixote emerge. A preservação desses "sinais" é fundamental, pois são eles que fornecem, segundo Jauss, pistas essenciais para despertar no receptor:

[...] a lembrança do já lido, enseja logo de início expectativas quanto a "meio e fim", conduz o leitor a determinada postura emocional e, com tudo isso, antecipa um horizonte geral de compreensão vinculada, ao qual se pode, então - e não antes disso -, colocar a questão acerca da subjetividade a interpretação e do gosto dos diversos leitores ou camadas de leitores (1994, p. 28).

Dessa maneira, ao longo da exposição do enredo, Gullar dá indicações ao leitor sobre a composição da personagem protagonista, baseado na conjunção de três elementos, que no decorrer da narrativa tornam-se indissociáveis: os livros de ca- valaria, a leitura e consequentemente a loucura. E para orientar essa percepção, o adaptador, ora imprimindo seu modo de dizer e ora recorrendo à voz de Cervantes, aponta ao leitor o que de fato esse precisa conhecer e/ou reconhecer sobre a trama que a ele se apresenta.

O importante é saber que nos momentos de ócio - que eram muitos- o referido fidalgo se punha a ler livros de cavalaria [...] E tanta era sua paixão por essas histórias que chegou a vender parte de suas terras para comprar livros de cavalaria [...] Enfim, envolveu-se tanto na leitura que passava as noites em claro e os dias a cochilar [...] De tanto ler e pouco dormir se lhe secou de tal maneira o cérebro, que perdeu a razão (CERVANTES, 2005, p. 11).

A referência aos livros, à leitura e à loucura vai surgindo no texto de forma encadeada, numa sequência linear, tendo como ponto de partida o contato do velho fidalgo com os livros, posteriormente, o encantamento desse pelo gênero e, por fim, a loucura, que surge como um efeito catártico, resultante das leituras que fizera das disparatadas histórias de cavalaria, que conforme dissera Cervantes "ni las entendiera el mismo Aristóteles, si resucitara para sólo ello" (CERVANTES, 2013, p. 70).

A paixão do protagonista pelos livros de cavalaria é anunciada ao leitor, como o motivo que leva o velho fidalgo a evadir-se da realidade e mergulhar no mundo ficcional dessas histórias. Vale ressaltar, que em várias outras partes do livro, o narrador retoma essa questão, com o intuito de lembrar ao leitor que o comportamento do protagonista deriva 
das alusões que esse faz às aventuras contidas nas novelas de cavalaria, que um dia lera.

Sua imaginação foi tomada por tudo o que nos livros lia - feitiçarias, contendas, batalhas, desafios, ferimentos, amores, tormentas e disparates inacreditáveis; de tal modo lhe pareceu plausível toda trama das sonhadas invenções nele contidas que, para ele, nada no mundo havia de mais verdadeiro [...] (CERVANTES, 2005, p. 11).

Após apresentar o leitor ao universo "cavaleresco" em que o velho fidalgo passa a habitar, Gullar inicia a narração da primeira saída de Dom Quixote, fazendo uma retomada ao capítulo anterior, "Tomadas essas providências [...]" (CERVANTES, p. 13). Essa retomada leva o leitor a recordar os elementos do universo quixotesco - a aldeia da Mancha, os livros, as armas, o cavalo Rocinante e a dama Dulcinéia de Toboso. Estando, portanto, mais familiarizado com o entorno "cavaleresco".

Baseando-se na falta de lucidez de Dom Quixote, Gullar seguindo os passos de Cervantes executa um desenho paródico $^{3}$ das novelas de cavalaria. O adaptador otimiza as ações do protagonista concentrando-as em micronarrativas, nas quais evidencia as alucinações do velho fidalgo, como a mola propulsora que desencadeia os conflitos.

Tais micronarrativas apresentam características estruturais semelhantes, sendo formadas de uma breve exposição, seguida de conflito e de um desfecho provisório, visto serem partes de uma macronarrativa. Esse tipo de narrativa configura-se como uma típica novela curta $^{4}$, modalidade na qual segundo Estébanez,

[...] se han señalado algunos rasgos característicos que las conforman y diferencian: los héroes, escenarios y planteamientos de las novelas cortas son fantásticos o idealistas, con poca relación con la realidad ${ }^{5}(1996$, p. 573).

Conforme registra o adaptador, a loucura de Dom Quixote provoca estranheza e perplexidade às outras personagens, sobretudo, pela veemência com que este acredita ser uma personagem dos livros de cavalaria, em consequência disso, Dom Quixote é ridicularizado pelas outras personagens, que passam a zombar de seu comportamento.

Em seguida, entregou-lhe o cavalo dizendo que tivesse muito cuidado com ele, pois se tratava de um animal precioso, o que deixou $o$ vendeiro surpreso. [...] $\mathrm{O}$ vendeiro, que era um tanto velhaco e já percebera a maluquice de seu hóspede, concordou com a tal cerimônia, já prevendo o quanto ia se divertir com aquilo (GULLAR, 2005, p. 14).

A zombaria provoca o riso nas personagens, o que segundo defende Propp, é o único tipo de riso que efetivamente deriva do cômico, isso porque "a comicidade costuma estar associada ao desnudamento de defeitos, manifestos ou secretos, daquele ou daquilo que suscita o riso" (1992, p. 170). Diante disso, vale lembrar Henri Bergson (1980), ao dizer que o riso se constitui como um produto dos costumes e das ideias de uma dada sociedade, tendo também um papel social. Por isso, é necessário que a obra literária leve em consideração o contexto de seu público-alvo, pois o que é risível para alguns, pode não ser para outros. 
Essa observação é válida, à medida que, a transposição do conteúdo humorístico ${ }^{6}$, eleva a capacidade intuitiva e o domínio literário do adaptador por extrair do texto-fonte a matéria-prima da paródia cervantina e fazê-la ressurgir em outro contexto estético, histórico e cultural.

Para trazer o conteúdo cômico presente no texto-fonte e torná-lo um conteúdo atrativo para seu público leitor, Gullar extrai a essência da paródia cervantina, isto é, o que há de mais engraçado na figura daquele cavaleiro às avessas - um homem velho, esquelético, feio, fraco e lunático. A forma física e psicológica de Dom Quixote mostra-se, portanto, afastada das noções estéticas que normalmente os jovens leitores possuem sobre a figura do herói, principalmente porque durante toda a infância, tais leitores tiveram contato com fábulas, contos de fadas, histórias em que os

\section{Obra fonte}

Había ya vuelto en este tiempo de su parasismo don Quijote, y, con el mismo tono de voz con que el día antes había llamado a su escudero, cuando estaba tendido en el val de las estacas, le comenzó a llamar:

- Sancho amigo ¿duermes? ¿Duermes, amigo Sancho?

-¡Qué tengo de dormir, pesia a mí respondió Sancho, lleno de pesadumbre y de despecho -; que no parece sino que todos los diablos han andado conmigo esta noche! [...]

(CERVANTES, 2013, p. 182, grifo nosso). heróis não apresentam defeitos, muito menos provocam riso em seus leitores.

Na primeira saída de Dom Quixote, o adaptador destaca três aspectos importantes do perfil do protagonista: a bravura (imitada dos cavaleiros), a loucura e a sua fragilidade física. Sendo os dois últimos aspectos os que mais pesam sobre o anti-herói cervantino, exatamente por serem os elementos que o coloca em situações embaraçosas. Já na segunda saída, a narrativa apresenta consideráveis alterações, com relação à insanidade de Dom Quixote, bem como pontua um redimensionamento do papel desempenhado por Sancho Pança ao lado de seu amo. Gullar dá velocidade à narrativa, por meio de textos resumidos, pela presença do discurso direto (diálogos entre Dom Quixote e Sancho), pela supressão de termos redundantes, conforme se observa nos trechos:

Obra adaptada

A esta altura, Dom Quixote, que já voltara a si do desmaio, chamou o escudeiro:

-Sancho amigo, estás dormindo? -Que dormindo que nada! Coitado de mim - respondeu ele. - Parece até que os diabos decidiram me atormentar esta noite (CERVANTES, 2005, p. 39, grifo nosso). 
Os episódios seguem uma única sequência narrativa, assim terminada uma aventura imediatamente Dom Quixote anuncia outra "- Ou muito me engano ou teremos uma aventura jamais vista [...]" (CERVANTES, 2005, p. 26). Essa continuidade das ações atrai e desperta a curiosidade do leitor em saber qual será o próximo conflito que o velho fidalgo irá protagonizar. A realidade, portanto, se acomoda com mais intensidade ao universo "cavaleresco". Desse modo, frades tornam-se feiticeiros e tropeiros, malfeitores. Gullar mostra ao leitor que não há limites para a imaginação de Dom Quixote, nem tão pouco para a de seu criador, que surpreende seu público ao interromper abruptamente a narrativa (justo no momento em que Dom Quixote enfrentava o escudeiro biscainho), dizendo: “[...] mas não se sabe o que aconteceu depois, porque, neste ponto, o narrador interrompeu a narrativa" (CERVANTES, 2005, p. 27).

Essa ruptura na narrativa provoca uma breve quebra na linearidade do enredo e coloca o leitor diante de uma técnica narrativa que lhe causa estranheza, por levantar a dúvida sobre a identidade do narrador, já que esse até então, comportara-se como um observador, relatando apenas o ocorrido, sem maiores envolvimentos com os personagens ou os acontecimentos. Nesse momento, o narrador é incorporado à narrativa, exercendo também função de personagem, uma vez que passa a atuar no enredo, conforme é possível notar através do uso da primeira pessoa em alguns trechos.

Estava eu um dia no Alcaná de Toledo quando vi um rapaz vendendo cadernos e papéis velhos a um trapeiro [...]. Perguntei-lhe de que ria e ele disse que à margem de uma das páginas estava escrito: "Dulcinéia del Toboso, tantas vezes referida nessa história, tinha melhor mão para salgar porcos do que qualquer outra mulher de Mancha" (CERVANTES, 2005, p. 28, grifo nosso).

No texto, verifica-se também o destaque dado à evolução de Sancho Pança no decorrer da narrativa, uma vez que passa de "um lavrador [...] homem de bem, mas de muito sal na moleira" (CERVANTES, 2005, p. 22) a amigo, confidente e conselheiro de Dom Quixote. Nos trechos que seguem, por exemplo, o escudeiro, que no início dessa segunda saída, é um tanto desprezado por Dom Quixote por não ser versado em histórias de cavalaria, potencialmente, vai assumindo lugar de prestígio ao lado de seu amo, sendo muitas vezes a voz que aparece, no intervalo entre o conflito e o desfecho, alertando o amo de seus recorrentes enganos. 
Episódio inicial

Capítulo VII

[...] Veja bem, meu amo, aquilo não são gigantes e sim moinhos de vento. E o que vosmecê pensa que são braços, na verdade são as pás dos moinhos [...]

Já se vê que não és versado nestas aventuras

- disse Dom Quixote. - E se estás com medo

afasta-te e te põe a rezar [...]

(CERVANTES, 2005, p. 24).
Episódio final

Capítulo XVII

- Proíbo-te de falar de agora em diante e de citar esses malditos refrãos!!

Sancho nada respondeu de imediato, mas depois de algum tempo, manifestou seu descontentamento:

- Se é pra ficar mudo, prefiro voltar para minha mulher e meus filhos, com os quais, pelo menos, poderei falar tudo o que deseje. Dom Quixote reconsiderou e prometeu suspender a proibição [...] (CERVANTES, 2005, p. 59).
Segundo Vieira (2006, p. 21), essa visibilidade ao escudeiro foi uma estratégia encontrada por Cervantes para tornar seu texto distinto das paródias publicadas em sua época. O texto precisava trazer uma novidade para que 0 leitor, diante das sucessivas desgraças e perdas de Dom Quixote, pudesse produzir mais do que gargalhadas.

Gullar, mesmo não tendo efetivamente o mesmo objetivo de Cervantes, demonstra a mesma preocupação, isto é, procura fornecer ao seu leitor mais que uma paródia burlesca, exatamente por entender que, assim como a obra fonte, seu texto poderia desgastar-se pela repetição constante de feitos cômicos, resultando numa monotonia estética. Assim, a evolutiva participação da figura do lavrador no enredo leva o leitor, por exemplo, a entender que o escudeiro, tanto sofre influência de seu amo, como também o influencia, o que gera em ambos uma consequente mudança de comportamentos.
Compreendendo, portanto, que a terceira saída como uma continuação da segunda, Gullar não faz divisão entre elas, mas as integra num todo. $\mathrm{O}$ adaptador não utiliza na introdução dessa parte, nenhuma nota ou prólogo esclarecendo ao leitor do que essa irá tratar. A divisão é feita na própria narrativa quando esse diz "Conta Cid Hamete Benengeli, na segunda parte desta história [...]" (CERVANTES, 2005, p. 80). Essa opção dá ao leitor a sensação de sequência, não sendo possível a esse reconhecer que ali começa a segunda parte de um livro que tem um afastamento temporal de dez anos do primeiro.

A narrativa gullariana é contínua, o que faz a distância entre as ações das personagens sejam ainda menor. Do capítulo XXI (que narra o segundo retorno de Dom Quixote para casa) ao capítulo XXII (que dá início a terceira saída), o que situa o leitor do distanciamento entre as narrativas é o tempo cronológico marcado logo no início do capítulo "[...] padre e barbeiro passaram quase um 
mês sem ver Dom Quixote" (CERVANTES, 2005, p. 80).

Gullar reduz e simplifica o enredo, no entanto, conserva a presença de novos elementos introduzidos por Cervantes. Dentre os quais estão a loucura menos aguda de Dom Quixote, a ascensão de Sancho e a introdução do bacharel Sansão Carrasco, personagem que irá ocupar, em certa medida, o lugar do padre e do barbeiro. A manutenção e a ampliação desses elementos permitem o desenvolvimento e a concretização de aventuras que foram planejadas na primeira parte.

O enredo da terceira saída de Dom Quixote e Sancho Panza rompe com qualquer ideia de obviedade, em comparação às duas outras saídas. Pois as aventuras passam também a serem arquitetadas por outras personagens e não somente pela loucura de Dom Quixote. Como é o caso do episódio em que Sansão Carrasco, a mando do padre e do barbeiro, disfarça-se de cavaleiro e desafia Dom Quixote a um duelo, acreditando que facilmente o venceria e o levaria de volta para casa. Conforme mostra o trecho a seguir:

- Raciocinemos, Sancho - ponderou Dom Quixote. - Na cabeça de quem pode caber que o bacharel Sansão Carrasco tenha se metido a cavaleiro andante para vir pelejar comigo? Sou porventura seu inimigo? Tudo isso só pode ser obra dos malignos magos [...] (CERVANTES, 2005, p. 110).

No capítulo XXXVI, surge outra referência ao livro $O$ Engenhoso Fidalgo Dom Quixote de la Mancha, que contém as primeiras aventuras de Dom Quixote e Sancho Pança. Novamente a narrativa transforma-se num jogo de espelhos. A ficção reflete-se e consolida-se pelo movimento mimético, construído da seguinte forma: A duquesa e o duque - tendo lido a primeira parte do livro escrito por Cid Hamete Benengeli, sendo, pois conhecedores das desventuras do velho fidalgo e de seu amo materializam uma "realidade" baseada nos sonhos e devaneios da dupla. Dom Quixote reconhecendo os elementos próprios do universo da cavalaria e Sancho vendo ali a possibilidade de tornar-se governador da tão sonhada ilha, não percebem a farsa, na qual são conduzidos a viverem.

Para que o leitor perceba a tal farsa, o adaptador envia pistas, como no episódio (capítulo IXL) em que o duque e a duquesa convidam Sancho e Dom Quixote para uma caçada. Quando estão no meio do bosque surge um demônio. Ao descrever a reação das personagens, o adaptador sugere que alguns sabiam do que aquilo se tratava.

Com essas e outras interessantes conversas, a noite chegou. Logo se ouviram, daqui e dali, sons de cornetas e outros instrumentos de guerra como se o bosque estivesse sendo atravessado por tropas de cavalaria. Em seguida soaram trombetas e clarins, retumbaram tambores e soaram pífaros, quase todos a um só tempo. O duque ficou pasmo, a duquesa também, Dom Quixote admirou-se, Sancho Pança estremeceu $e$ mesmo aqueles que sabiam qual era a causa daquilo se espantaram (CERVANTES, 2005, p. 143, grifo nosso).

Somente no final do capítulo IXL é que $o$ adaptador revela explicitamente 
a farsa, na qual estava Dom Quixote e Sancho Pança completamente envolvidos.

Nesta altura já vinha despontando a aurora. Foi então que os duques, satisfeitos com a caçada e com o bom resultado da farsa que haviam montado, voltaram para o castelo em companhia de Dom Quixote, Sancho Pança, seus caçadores e criados (CERVANTES, 2005, p. 148).

Gullar preocupa-se em manter apenas as passagens que efetivamente fariam falta para que o leitor compreendesse $o$ que leva Dom Quixote à Barcelona, visto que a narrativa da segunda saída já havia informado que este se dirigia à Saragoça. Para explicar a mudança de percurso, o adaptador mantém resumidamente o episódio do encontro de Roque Bandoleiro com Dom Quixote, pois é por meio dele que o fidalgo chega até Dom Antônio Moreno, anfitrião que recebe Sancho e seu amo em Barcelona. A presença de Dom Moreno é imprescindível, pois é ele quem desvenda, no capítulo seguinte, a farsa de Sansão Carrasco, que disfarçado de cavaleiro da Branca Lua propõe duelo ao fidalgo. Duelo no qual Dom Quixote acabou derrotado e tendo que cumprir com o que tinha ficado determinado ao perdedor - voltar para sua cidade e afastar-se da cavalaria por um ano.

O leitor acompanha a descaracterização e, quanto mais avança na leitura, mais é conduzido a perceber que a imagem inicial de Dom Quixote se esvazia progressivamente. Desse modo, evadido do universo "cavaleresco", o fidalgo sugere a Sancho tornarem-se pastores.
Essa referência preservada por Gullar fora realizada por Cervantes como uma alusão às novelas pastoris ${ }^{7}$, uma espécie de metáfora, que representa o retrocesso de Dom Quixote, ao deixar de viver as aventuras cavalerescas para se entregar à pacífica vida do campo. O leitor de Gullar certamente não perceberá a ironia, nem tão pouco o propósito de Cervantes, analisando a passagem como uma reação de Dom Quixote diante de sua desilusão.

A partir do prenúncio da morte do protagonista, a narrativa gullariana evidencia o processo de transformação que o protagonista passa a se ver diante da morte. Tal processo marca, por exemplo, a mudança de opinião do fidalgo com relação aos livros de cavalaria, que agora os reconhece como causadores de toda sua desgraça.

Quanto mais próxima a morte está de Dom Quixote, mais relatos de sua lucidez são registrados pelo adaptador. A morte vai sendo cada vez mais associada à ideia de transformação, pois por meio dela, o velho fidalgo passa de louco a ajuizado e de Dom Quixote a Alonso Quijano. E, assim chega-se ao fim do ciclo de aventuras de Dom Quixote.

-Senhores - disse Dom Quixote -, vamos passo a passo, pois nos ninhos de outrora já não há pássaros agora. Eu estive louco e já estou no meu juízo perfeito, fui Dom Quixote e agora sou, como já disse, Alonso Quijano (CERVANTES, 2005, p. 220).

Com base na leitura realizada, infere-se que o percurso narrativo eleito por Gullar centra-se nas três saídas de Dom 
Quixote. Na primeira saída, ele mantém a essência da novela curta de Cervantes e evidencia a incorporação do velho fidalgo ao universo "cavaleresco"; na segunda, faz a inclusão do escudeiro e a amplificação das aventuras de Dom Quixote; na terceira e última saída, inclui novos elementos à narrativa, bem como apresenta uma considerável alteração no comportamento de Dom Quixote e Sancho Pança.

\section{Leitura, estilo e ilustração em Dom Quixote: cruzamento de horizontes pelo viés da adaptação}

Neste tópico serão analisados o assunto, do estilo e do meio, pois a adaptação da forma já fora analisada no tópico anterior, no qual se tratou das estratégias literárias de Gullar.

A adequação do assunto refere-se à seleção que o adaptador faz dos temas que devem permanecer ou que devem ser suprimidos por não serem apropriados ou não estarem no nível de entendimento e de interesse do leitor. Já a adaptação do estilo ocorre quando a estrutura linguística dos leitores é limitada e exige que o adaptador deixe seu discurso mais acessível, fazendo, por exemplo, alterações na sintaxe, transformando períodos longos em frases curtas e diretas. Por fim, a adaptação do meio, na qual os paratextos e toda a parte tipográfica do livro são construídas a partir do perfil do leitor, por isso configuram-se como recurso importante nas estratégias do adaptador ou da editora para seduzir seu público alvo.

Gullar exclui as histórias intercaladas, dentre as quais a da pastora Marcela (capítulo XII), da Dama Dolorida e de Ana Félix e Dom Gregório, histórias em que repousam temas como o desengano amoroso, amor, a vingança, mas que segundo o adaptador são:

[...] histórias muito românticas, parecem refletir uma preocupação de Cervantes: a de que seus anti-heróis não fossem capazes de manter, por si sós, o interesse do leitor. Arrisco-me a afirmar que elas não pertencem organicamente à narrativa e, a rigor não fazem falta ao livro (CERVANTES, 2005, nota do tradutor).

O episódio da pastora Marcela, por exemplo, trata-se da história de uma jovem de grande beleza e única herdeira da fortuna de um tio. Essa teve a infelicidade de ser desejada por Grisóstomo, um jovem pastor, por quem não sentia nenhum apreço. Não suportando a rejeição de Marcela, esse se suicida, deixando uma narrativa acusando Marcela de sua morte. Os amigos do jovem pastor querem vingar a morte do amigo, punindo Marcela. Mas quando eles estão reunidos contando a Dom Quixote como a personagem é má e destruidora, ela aparece e se defende dizendo que o fato de ser amada por Grisóstomo, não a faz ter que ceder aos seus desejos, nem muito menos por ser mulher ter que casar-se para buscar proteção. Diz ser uma mulher livre para ir e vir, desimpedida, e capaz de cuidar 
de seus afazeres, de sua fazenda, sem ter que estar com um homem ao seu lado.

Apesar do distanciamento temporal, Cervantes aborda uma temática, como se vê, muito atual, isto é, a condição feminina, tema que se expandiu e que ao longo dos anos, mobilizou revoltas, movimentos feministas, gerando a criação de leis em defesa e de apoio à mulher na luta por igualdade social. Ao excluir esse episódio, Gullar deixa de explorá-lo como recurso discursivo de grande valor e que poderia levar o jovem leitor a adotar uma postura crítico-reflexiva diante da temática em questão.

Ao contrário da estratégia usada por Cervantes para atrair seu leitor, Gullar prefere centrar-se nos diálogos, visto considerar que é essencialmente sobre elas que a narrativa cervantina se sustenta. Assim como relata.

Dom Quixote ficou famoso pelas loucuras que praticou como lutar contra moinhos de vento julgando que fossem gigantes ou atacar rebanhos de carneiros por achar que se tratassem de um Exército inimigo. São episódios divertidos, cheios de humor. No entanto, onde de fato se apreende o sentido profundo daquelas bravatas, as lições de vida e a sábia insensatez do cavaleiro andante, é nos diálogos (CERVANTES, 2005, p. 1, grifo nosso).

Gullar parece seguir os passos do mestre Monteiro Lobato (1882-1948), que em sua adaptação, Dom Quixote das crianças (1936), conforme Prado (2008, p. 5), "resume drasticamente o clássico, prendendo-se apenas às aventuras mais famosas da dupla cervantina. Suprime as descrições, as digressões e os relatos de novelas ou outros episódios que alongam o original".

A supressão e condensação de assuntos é muito comum quando o adaptador ou a editora preveem o público-alvo, principalmente se esse público é o escolar, pois segundo lembra Monteiro (2010, p. 45) existem regras para compor uma adaptação, sobretudo para aquelas que são adotadas pela escola, conforme enumera.

1. Selecionar o quanto do enredo do texto primeiro deve permanecer;

2. produzir um texto novo - uma nova narrativa - com linguagem acessível ao perfil do aluno;

3. não desrespeitar os valores éticos $\mathrm{e}$ morais recomendados pelo sistema educacional vigente na atualidade.

Ferreira Gullar mostra-se um adaptador atento a tais regras, visto que em sua adaptação ele opta pela redução do volume da obra, preocupa-se em adequar a linguagem, bem como aborda temas pertinentes aos interesses do seu público leitor. Nesse sentido, pode-se dizer que Gullar adota a postura de mediador entre a obra fonte e o leitor juvenil. Essa prática, segundo descreve Carvalho, recai sobre duas implicações: fazer com que suas estratégias textuais possam propiciar "o cruzamento dos horizontes de expectativas da obra e do leitor", não deixando de considerar que existe uma "distância estética entre a obra na sua textualidade primária e o leitor infantil e juvenil, o que pode impedir uma inte- 
ração entre obra/leitor" (2006, p. 55). A outra implicação destacada por Carvalho (2006, p. 55) trata do:

[...] estabelecimento de uma reorganização do sistema literário, constituído, inicialmente, por autor/obra/leitor, para um novo formato ou desenho formado por autor/ obra/leitor-adaptador/obra adaptada/leitor infanto-juvenil [sic], objetivando, posteriormente, retornar organização primeira do sistema literário (autor/obra/leitor) por meio do encontro do leitor já formado/maduro com a obra literária não mais mediada pelo adaptador.

Gullar é, pois, o autor-adaptador-mediador, que ao tomar a responsabilidade de apresentar a estética de Dom Quixote ao leitor juvenil, preferiu dar destaque as questões que considerou mais próximas aos interesses de seu público e ao universo a que este pertence. Dessa forma, preserva temas como a leitura, a amizade, a utopia, a essência humana, que povoam a narrativa cervantina, e que, segundo as estratégias de Gullar, são mais evidentes, nos episódios vividos por Dom Quixote e seu fiel escudeiro.

$O$ primeiro tema que surge na narrativa é a leitura. Esse tema é introduzido por Dom Quixote que revela, desde o princípio, ser um profundo conhecedor da literatura e da cultura de sua época. Ao longo da narrativa o adaptador ressalta o amplo conhecimento do fidalgo, preservando trechos em que esse se reporta a autores e a personagens dos livros de cavalaria e também da mitologia grega.
Ao se ver sozinho, Dom Quixote deixou a posição um tanto vexatória em que se encontrava, subiu ao topo de um penhasco e ali se pôs a meditar; perguntou a si mesmo se seria melhor imitar o cavaleiro Rolão, também chamado Orlando, em suas loucuras, ou Amadis de Gaula, que nunca perdeu o juízo e nem por isso deixou de se tornar famoso e admirado [...] (GULLAR, 2005, p. 60, grifo nosso).

- Carreiro, cocheiro ou o diabo que sejas, não tardes a dizer-me quem és, aonde vais e que gente levas nessa tua carroça, que mais parece a barca de Caronte do que carreta comum (CERVANTES, 2005, p. 98, grifo nosso).

Para o leitor mais experiente, que tem em seu repertório, leituras mais complexas, como é o caso dos clássicos da mitologia grega, perceber e compreender o sentido que a referência a Caronte tem no texto, certamente não é dificuldade, mas para o leitor juvenil, que geralmente não é exposto a esse tipo de leitura, a apreensão do sentido é realizada por meio do contexto.

$\mathrm{O}$ adaptador deixa pistas, como no trecho em que se refere às pessoas que iam na carreta "O homem que guiava a mula era feio como o demônio. A primeira figura que se destacou aos olhos de Dom Quixote foi a da própria morte" (CERVANTES, 2005, p. 97), levando o leitor a deduzir que a personagem mitológica se tratava de uma figura diabólica. Dessa forma, dispensou-se o uso de nota esclarecedora, como a usada na obra fonte, em que Cervantes explica que Caronte "es el barquero infernal encargado de transportar las almas de los muertos al inferno" (2013, p. 622). 
A manutenção dessas referências reforça a temática sobre a leitura, apresentando-a como uma prática que amplia a experiência humana, dada seu caráter mimético. No entanto, Dom Quixote não é o único que manifesta a prática da leitura, quer também se faz presente na vida de outras personagens. Assim como é possível constatar no capítulo VI, quando o padre e o barbeiro são chamados para atear fogo nos livros de cavalaria, a pedido da sobrinha de Dom Quixote. Antes de atenderem ao pedido, começam uma espécie de julgamento, no qual vão expressando certa relação de intimidade com alguns daqueles livros.

$\mathrm{E}$ assim foram examinando um por um: o primeiro que o barbeiro lhe passou foi Os Quatro de Amadis de Gaula, o primeiro livro de cavalaria que se imprimiu na Espanha. -Vamos queimá-lo - disse o padre, mas o barbeiro discordou, alegando que era também o melhor de todos os livros do gênero.

Decidiram poupá-lo. Assim passaram em revista livro por livro [...] Já cansado, o padre opinou que se deveria encerrar o exame e pôr fogo em todos os demais livros, mas o barbeiro já havia aberto um outro que se chamava Lágrimas de Angélica.

- Eu é que as choraria se tivesse mandado queimar este livro, porque seu autor foi um dos mais famosos poetas do mundo e não apenas da Espanha, além de ter traduzido muito bem algumas fábulas de Ovídio (CERVANTES, 2005, p. 21).

Notadamente o padre mostra-se mais favorável à queima dos livros do que o barbeiro, tal fato será explicado no capítulo XIX, quando o padre revela o porquê de sua rejeição aos livros de cavalaria.

-Na verdade - disse o cônego -, de minha parte penso que os livros de cavalaria são prejudiciais à sociedade. São contos disparatados que só visam a divertir, ao contrário das fábulas moralizantes que deleitam e ensinam ao mesmo tempo (CERVANTES, 2005, p. 70).

Por meio do relato, o padre também se mostra um ávido leitor, tendo conhecimento suficiente tanto para condenar um gênero por seu conteúdo evasivo, quanto para exaltar outro por trazer lições de comportamento ético e moral.

A leitura é, pois, representada como uma prática que provoca efeitos sobre seus leitores, levando-os a manifestar as mais diversas reações. O cura e o barbeiro, por exemplo, ora esboçam apreço, ora rejeição diante dos livros, reações que se alternam ao se reportarem a autores, obras e personagens.

Apesar de o trecho trazer apenas parte resumida do capítulo, ele é suficiente para que o leitor perceba também os horizontes de leitura da época da publicação de Dom Quixote, pois ao referenciar outras histórias de cavalaria, o adaptador envia ao leitor pistas sobre o gênero em questão, viabilizando a fusão dos horizontes da obra fonte e do receptor.

Com base nessas colocações, pode-se dizer que o adaptador reduz o tema tendo como objetivo tornar o texto mais compreensível para seu receptor. Por isso, molda seu texto para que esse se torne mais funcional, pois conforme lembra Umberto Eco:

Um texto é um produto cujo destino interpretativo deve fazer parte do seu próprio mecanismo generativo: gerar um texto significa atuar segundo uma estratégia que inclui as previsões dos movimentos do outro - tal como acontece em toda a estratégia (1993, p. 57).

Preservando ao máximo o estilo cervantino, Gullar ao fazer a adaptação de estilo, também faz do diálogo um dos seus maiores acertos estilísticos, pois por meio desse recurso, as personagens são individualizadas por sua forma de falar. 
As adequações de termos e expressões realizadas por Gullar, geralmente, são feitas por meio de substituição de termos

Texto fonte

[...] se llegó a la puerta de la venta, y vio a las dos distraídas mozas que allí estaban, que a él le parecieron dos hermosas doncellas 0 dos graciosas damas [...] (CERVANTES, 2013, p. 77, grifo nosso).

A adequação de destraídas mozas por moças de vida fácil é uma substituição equivalente, pois no contexto linguístico da língua fonte a expressão é explicada na nota de rodapé 173 como: fulanas, sinvergüenzas. O primeiro termo segundo o dicionário Señas (2010, p. 597) significa

Texto fonte

El barbero, que, tan sin pensarlo ni temerlo, vio venir aquella fantasma sobre si, no tuvo otro remedio, para poder guardarse del golpe de la lanza, si fue el dejarse caer del asno abajo; y no hubo tocado al suelo, cuando se levanto más ligero que un gamo y comenzó a correr por aquel llano, que no le alcanzara el viento (CERVANTES, 2013, p. 222, grifo nosso). e expressões equivalentes na língua fonte. Conforme é possível notar no quadro que segue.

\section{Texto adaptado}

À porta da venda estavam duas moças de vida fácil que the pareceram ser damas graciosas ou formosas donzelas (CERVANTES, 2005, p. 13, grifo nosso).

"mujer que mantiene relacionamento a cambio de dinero $\rightarrow$ prostituta" contendo, portanto, a mesma conotação da língua-alvo.

Em outro trecho, o adaptador realiza substituição, dessa vez, para atender uma necessidade de adequação cultural.

\section{Texto adaptado}

O barbeiro, ao ver avançar em sua direção aquele cavaleiro armado de lança, levou tamanho susto que caiu do jumento; mal tocou no chão, levantou-se e, mais ligeiro que uma lebre, saiu disparado veloz como o vento (CERVANTES, 2005, p. 51, grifo nosso).

As expressões em destaque têm o mesmo sentido em seus contextos de atuação, pois os animais referidos (gamo e a lebre) são conhecidos por serem hábeis corredores. No entanto, não seria viável a tradução integral, pois a substituição equivalente do termo gamo por um correspondente em português seria gazela ou veado, o que, sem dúvida, causaria estranheza ao leitor, dada a conotação que tais termos exercem na língua-alvo.

Conforme a leitura empreendida, a adaptação de estilo realizada por Gullar teve, dentre outras finalidades, a de dialogar com o jovem leitor. A estilística 
empregada, respeitando o limite permitido pelo gênero e pela obra fonte, dirige-se a um receptor em fase de transição que não tem a maturidade do leitor adulto e nem a ingenuidade do público infantil. Ciente disso, o adaptador buscou, por meio de procedimentos tradutórios e adaptativos, proporcionar a esse jovem uma leitura mediadora, na qual esse pudesse tanto se surpreender pela novidade estética, quanto se reconhecer nas marcas linguísticas e culturas deixadas pelo adaptador.

Passa-se, portanto, a análise da adaptação do meio, momento em que este tópico se volta para o objeto livro. Serão discutidos aspectos relacionados à composição gráfica da adaptação gullariana, tendo como objetivo verificar de que modo os recursos gráficos colaboram para a recepção do texto adaptado.

A adaptação de Gullar apresenta ${ }^{8}$ impressão e acabamento em papel couché $90 \mathrm{~g}$, corpo 13/15, contendo $224 \mathrm{p}$. divididas em 57 capítulos, que também trazem ilustrações de Gustave Doré.

$\mathrm{O}$ primeiro contato do leitor com o livro inicia-se com a visualização da capa. Esse elemento funciona como uma espécie de embalagem, na qual constam algumas informações primárias sobre 0 produto. Dependendo da forma como se apresenta, a capa tem o poder de seduzir ou não o leitor a continuar a leitura, pois, segundo Ramos e Pannozo:
A capa e a contracapa são limites materiais das histórias ou poemas contidos no interior do livro, ambas desencadeiam informações e fazem emergir hipóteses do que se pode esperar do texto. O efeito desta apresentação é semelhante ao de uma embalagem que, por suas características suscita o desejo da posse, guarda um mistério, ativa a curiosidade e, ao mesmo tempo, sinaliza algumas possibilidades à mente de quem se aproxima desse objeto (2005, p. 166).

Os elementos que compõem a capa da adaptação de Gullar dialogam com o gênero "cavaleresco". O título, por exemplo, é grafado com letras que lembram a escrita medieval e a ilustração impressa no centro da capa traz a imagem de Dom Quixote e Sancho Panza. A presença desses elementos o leitor pode inferir que se trata de uma história de cavalaria.

Na composição do título verifica-se uma acentuada distinção no tamanho das letras que grafam o nome Dom Quixote. O termo "Dom" vem na cor preta e de tamanho reduzido em relação Quixo$t e$, que vem em destaque na cor branca, o resto do título de la Mancha está logo abaixo, com letras ainda mais reduzidas. Conforme observa-se na imagem seguinte: 
Figura 1 - Capa do livro Dom Quixote

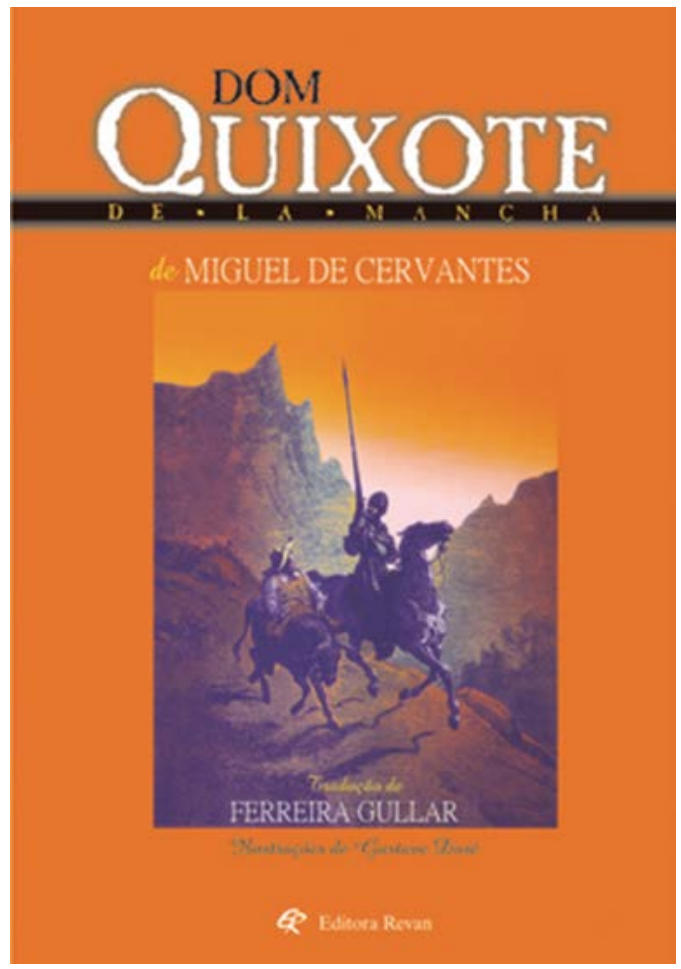

Fonte: CERVANTES, 2005.

A disposição gráfica deixou o título mais conciso e centrado no nome do protagonista. Essa forma de apresentação revela-se como uma estratégia editorial, à medida que conduz e concentra a atenção do leitor para um único foco. O destaque dado ao nome QUIXOTE, pode ter sido usado por causa da popularidade da personagem ou apenas para evidenciá-lo como o elemento central da história, de uma forma ou de outra o uso não foi arbitrário.

Depois do título, vem o nome do autor da obra fonte, Miguel de Cervantes. Após a ilustração da tela de Gustave Doré vem em letras cursivas e minúsculas o termo "Tradução" e logo depois o nome de Ferreira Gullar em caixa-alta. Conforme se verifica, o nome do Cervantes é mais evidenciado do que o de Gullar. Diante dessa observação, Carvalho diz que

\section{[...] se o autor e o adaptador são conhecidos e legitimados pela crítica literária, o nome do adaptador não pode sobrepor-se ao do autor, uma vez que a finalidade é colocar em pri- meiro plano a obra adaptada (2006, p. 68).}

Outro aspecto relevante e que não poderia deixar de ser tratado é a classificação do livro impresso na capa como uma tradução. De fato, o texto não deixa de apresentar técnicas tradutórias, mas a classificação contradiz com o texto contido na contracapa, que diz:

Escolhido recentemente como o melhor livro de todos os tempos por uma comissão de escritores notáveis de 54 países, DOM QUIXOTE DE LA MANCHA chega agora às livrarias do Brasil em tradução e adaptação de Ferreira Gullar, considerado o maior poeta brasileiro vivo (grifo nosso).

Gullar, em Nota do tradutor, também vai de encontro à classificação impressa na capa, quando diz: "Esta que você tem em mãos é uma tradução adaptada." Com base nessas contradições, verifica-se que o emprego do termo tradução tem por finalidade conferir ao texto de Gullar uma noção de fidelidade com relação ao texto fonte. Essa classificação mostra-se como mais uma estratégia editorial para garantir maior status ao livro apresentado, pois no meio literário o termo adaptação é, geralmente, associado à simplificação ou empobrecimento dos textos originais (AMORIM, 2005). 
Apesar da tentativa editorial de afastar o termo adaptação da obra, os procedimentos adaptativos sobrepõem-se aos tradutórios. $\mathrm{Na}$ adaptação do meio em diversos aspectos nota-se que as alterações revelam a preocupação do adaptador em facilitar a vida de seu leitor. A redução do volume do texto fonte é uma das mais notórias modificações, pois a narrativa de Cervantes é composta por dois volumes, o primeiro composto por 52 capítulos e o segundo por 74 capítulos, somando um total de 126 capítulos, distribuídos em 1.057 páginas.

Já o texto de Gullar apresenta um único volume, no qual aglutina as duas partes de forma contínua. O texto completo é formado por 57 capítulos e 222 páginas. Os capítulos são marcados apenas por números romanos, não contendo subtítulo, como no texto fonte, em que o subtítulo resume o que será tratado do capítulo. Exemplo: Texto fonte - CAPÍTULO II - Que trata de la primera salida de su tierra hizo el ingenioso don Quijote (CERVANTES, 2013 p. 75).

A manutenção dessa síntese anteciparia o conteúdo da narrativa e consequentemente levaria o público a se conformar com a informação e interromper a sequência narrada. Dessa forma, a supressão do subtítulo na adaptação é justificável, à medida que aguça a curiosidade do leitor e o estimula a prosseguir na leitura. Para tornar os capítulos ainda mais atraentes ao leitor juvenil, Gullar faz uso de ilustrações da obra cervantina feitas por Gustave Doré. Tais imagens contribuem para o entendimento do leitor, uma vez que a relação dialógica estabelecida entre texto e imagem, o conduzem a participar do jogo narrativo, no qual acaba também sendo um participante ativo, pois segundo diz Pereira ao lembrar Riitta Oittinen (1993):

O leitor é também participante do diálogo, $\mathrm{e}$ forma com o texto e a imagem uma relação dialógica, ao visualizar a "forma" e o "cenário" da história verbal, de modo a construir, não apenas o ritmo, como as relações de inseparabilidade, igualdade e diferença entre as duas narrativas (2003, p. 59).

As ilustrações de Gustave Doré foram vistas pela primeira vez numa edição francesa de Dom Quixote lançada em 1863, que continha trezentos e setenta e cinco desenhos, desde então, a imagem de Dom Quixote e seu escudeiro passaram a circular pelo mundo em muitas traduções e adaptações. O valor artístico e estético das ilustrações de Doré popularizou a imagem das personagens cervantinas de maneira tão singular, que, segundo as palavras de Gonçalo Jr.:

Quase um século e meio depois de publicar a primeira edição com seus desenhos, o francês mantém uma marca tão forte em relação ao personagem que os dois são hoje, indissociáveis. Não é possível mais idealizar um imaginário popular outra figura de D. Quixote senão a de Doré. Talvez seja esse um acontecimento único no mundo da literatura, uma vez que não houve uma composição combinada e os dois autores viveram em tempos diferentes, com dois séculos de espaço de tempo (2005, p. 12).

A escolha de Gullar pelas ilustrações de Doré pode estar relacionada a esse fato. Além disso, a aproximação estética 
entre o texto e a imagem fornece à narrativa gullariana um tom épico, o que consequentemente gera no leitor do século XXI um cruzamento de horizontes, já que esse é, normalmente, exposto a animações, carregadas de cores, movimentos e abstrações de toda ordem, ou seja, a uma arte gráfica cada vez mais ligada ao mundo da tecnologia.

No texto literário ilustrado, conforme discorre Pereira,

[...] o leitor realiza uma leitura estética, sem preocupações em performar instruções corretamente, mas fundamentado na experiência humana com a literatura e considerando suas razões, gostos e reações individuais (2003, p. 60).

$\mathrm{Na}$ narrativa gullariana, o encontro das palavras com as imagens ocorre de forma interativa. As ilustrações estão dispostas no texto com o objetivo de ampliar as possibilidades de percepção do leitor, que por meio delas, visualiza, concretiza e até mesmo acrescenta o que está representado pelas palavras.

Diante da grande quantidade de ilustrações presentes na adaptação selecionou-se algumas dessas gravuras, buscando verificar de que maneira elas dialogam com o texto de Gullar, bem como compreender que função exercem na narrativa. Para orientar esta leitura, utilizou-se como base os estudos de Nilce Maria Pereira (2006) que aponta algumas formas de interação entre as gravuras e o texto traduzido.

Antes mesmo da narração do primeiro capítulo, a adaptação traz a gravura de Dom Quixote sentado numa poltrona, lendo um livro, empunhando sua espada e cercado de elementos imaginários. Na sequência, o adaptador apresenta o protagonista ao leitor, destacando suas características físicas e psicológicas, bem como evidencia a imaginação e a loucura que o arrebatara.

Figura 2 - Quando o velho fidalgo enlouquece de tanto ler

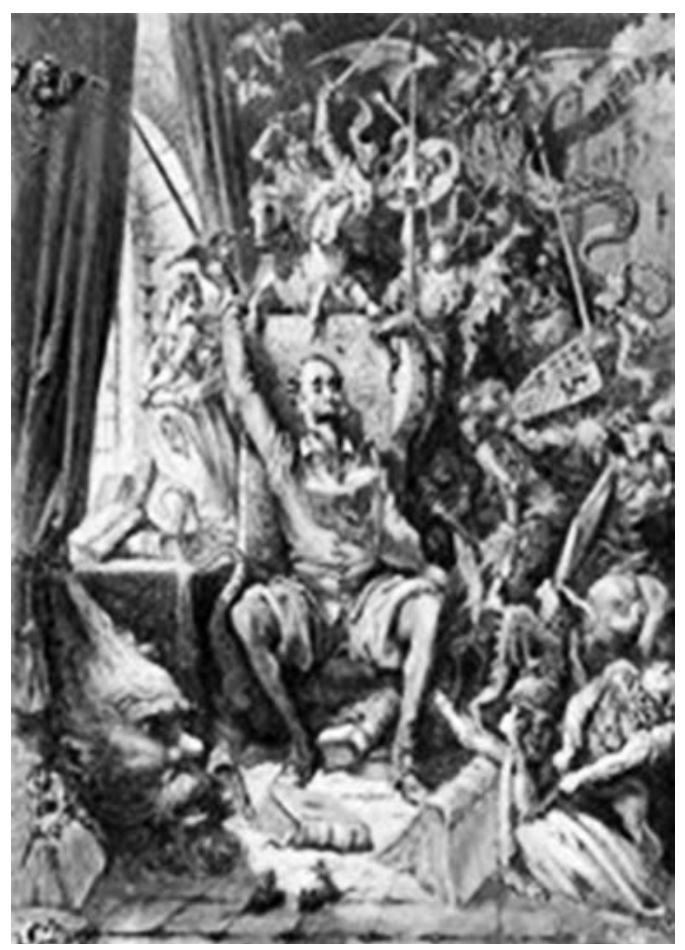

Fonte: CERVANTES, 2005.

A idade de nosso fidalgo beirava os 50 anos: era de complexão rija, seco de carnes, enxuto de rosto [...] De tanto ler e pouco dormir, se lhe secou de tal maneira o cérebro, que perdeu a razão. Sua imaginação foi tomada por tudo o que nos livros lia - feitiçarias, contendas, batalhas, desafios, ferimentos, amores, tormentas e disparates inacreditáveis (CERVANTES, 2005, p. 11). 
Como se observa a ilustração corresponde ao texto, pois a figura que $o$ leitor visualiza condiz com a descrição textual. $\mathrm{Na}$ imagem a personagem é apresentada exatamente com as mesmas características físicas descritas textualmente. Além disso, é possível também observar livros, cavaleiros andantes, donzelas, espadas, escudos, elementos que aludem às histórias de cavalaria, representando a imaginação do velho fidalgo.

No capítulo II, a correspondência entre texto e imagem é ainda mais evidente. Gullar parece descrever a cena ilustrada. Os elementos textuais e imagéticos interagem no mesmo ritmo. Essa é uma característica recorrente às ilustrações que encabeçam os capítulos, bem como esta que segue.

Figura 3 - O que aconteceu a Dom Quixote quando saiu da venda

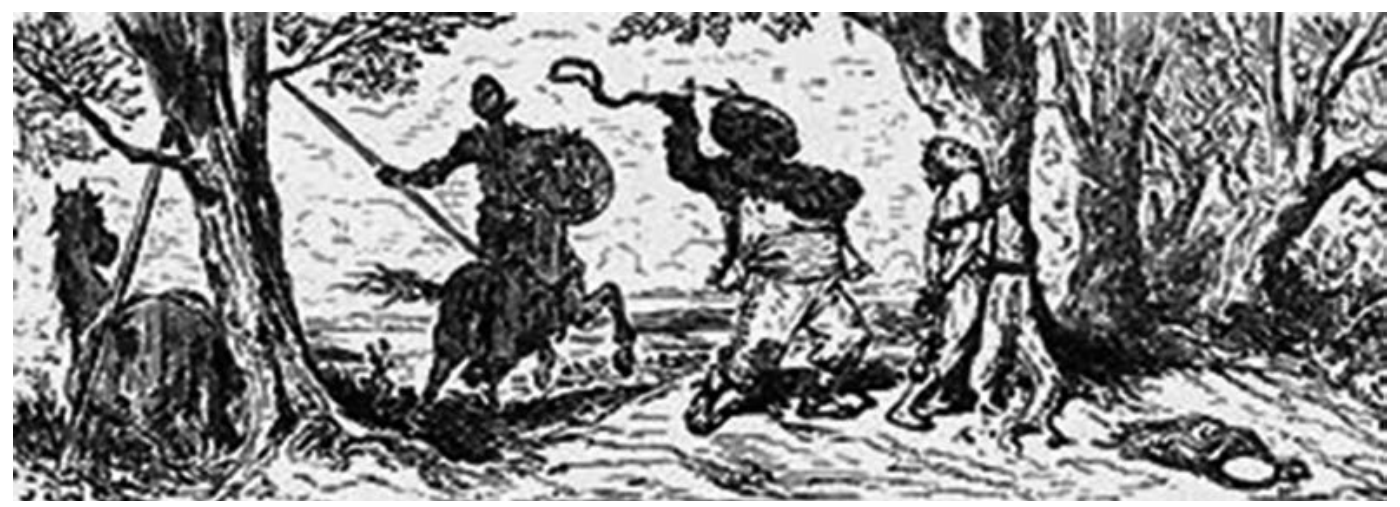

Fonte: CERVANTES, 2005.

Puxou as rédeas e fez Rocinante entrar no bosque na direção de onde vinham as vozes e logo se deparou com a seguinte cena: um rapaz de 15 anos, amarrado a uma árvore de barriga, era espancado por um lavrador de bom tamanho, que empunhava um cinturão (CERVANTES, 2005, p. 16).
No final do capítulo VI, tem-se a primeira imagem de Dom Quixote e Sancho Pança. Ilustração que marca a segunda saída do protagonista, agora na companhia de seu escudeiro. Nela o leitor é capaz de visualizar o aspecto físico de Sancho, já que em nenhum momento do texto são descritas as características dessa personagem, dessa maneira a imagem tem a função de acrescentar uma informação. 
Figura 4 - A segunda saída: Dom Quixote e Sancho Pança

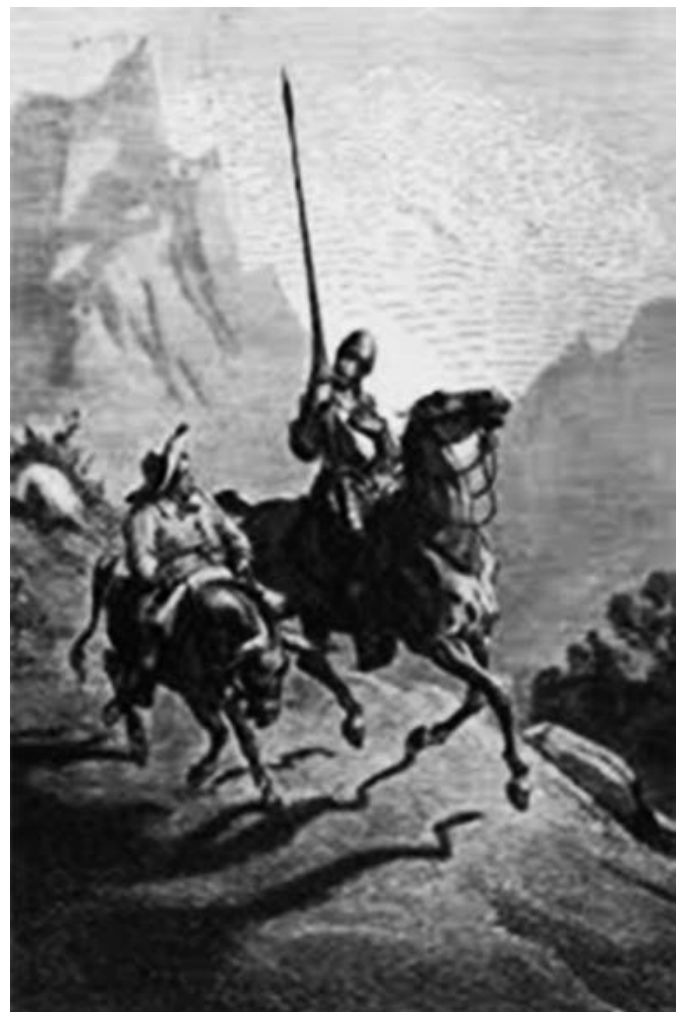

Fonte: CERVANTES, 2005.

Algumas imagens também exercem a função de antecipar os acontecimentos narrados. No capítulo XXXI, a ilustração mostra o carreiro levantando a grade da jaula onde se encontra um leão. Na imagem aparece Dom Quixote com escudo e espada pronto para enfrentar a fera. Sancho e o outro cavaleiro retirando-se do lugar. A imagem só será descrita na página seguinte, quando finalmente $o$ leitor compreenderá a ilustração.
Figura 5 - Dom Quixote desafia os leões

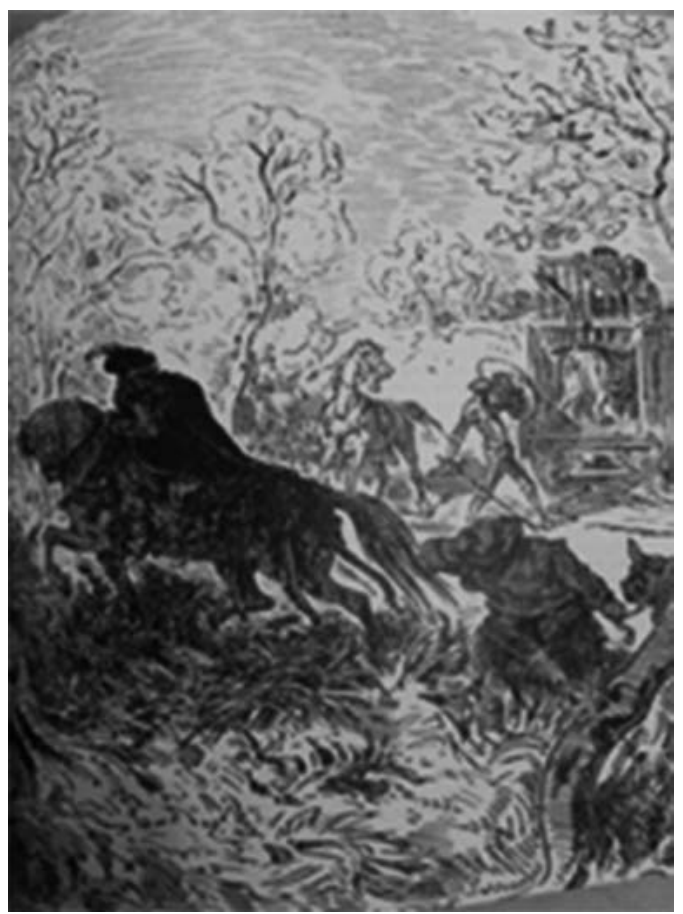

Fonte: CERVANTES, 2005.

[...] Depois disso, o carreteiro ainda tentou convencer o cavaleiro andante a não defrontar-se com os leões, mas isto nada adiantou; o mesmo tentou o fidalgo de Capa Verde, inutilmente. Diante disso, ele, Sancho e os demais trataram de se afastar, antes que os leões fossem soltos. [...] Enquanto o tratador dos leões se aprestava para abrir as jaulas, Dom Quixote achou que melhor seria enfrentá-los a pé, já que Rocinante poderia assustar-se com eles. Desmontou e desembainhou a espada, postando-se em frente da jaula à espera dos leões (CERVANTES, 2005, p. 114).

Diante do exposto, pode-se dizer que as ilustrações contidas na adaptação de Gullar seguem uma sequência cronológica de ações, relacionadas ao tempo dos episódios narrados na obra fonte. A escolha das gravuras, não é arbitrária, 
visto que, tais ilustrações são artifícios usados com a intenção de chamar e prender a atenção do leitor, sendo por vezes capaz de interagir o texto, colaborando para uma melhor interpretação/leitura.

\section{Conclusão}

Adaptar uma obra como Dom Quixote de La Mancha, de Miguel de Cervantes, para o perfil do jovem leitor contemporâneo, não se constitui numa tarefa simples: o rebuscamento na linguagem, os exageros nas descrições e o excesso de referências a personagens e histórias, alongaram a narrativa e tornaram-se, com o passar dos anos, obstáculos para o leitor inexperiente. Para superar essas dificuldades e aproximar a obra fonte do leitor juvenil, cada adaptador elege seus procedimentos. Nesta pesquisa, buscou-se conhecer as estratégias utilizadas por Ferreira Gullar na adaptação do clássico cervantino, com vistas a torná-la uma leitura atrativa e acessível ao seu público-alvo.

No primeiro tópico estudado, verificou-se que o adaptador faz a caracterização física e psicológica do protagonista, bem como localiza o tempo e o espaço em que esse está inserido; na segunda saída introduz Sancho Pança, e dinamiza a narrativa, por meio de episódios curtos, carregados de ação, intercalados por discursos direto e indireto e acompanhados de ilustrações que dão mais movimento às cenas.
No segundo tópico, analisou-se a adaptação do assunto, do estilo e do meio. Com relação à adaptação do assunto, viu-se que o adaptador priorizou a temática da leitura. E para tratar desse tema, Gullar preservou trechos em que se percebe diferentes reações provocadas pela leitura das novelas cavalerescas. Por meio das vozes do narrador e de algumas personagens, $o$ adaptador apresenta o horizonte de leitura da época de Cervantes, mostrando aos leitores que as histórias de cavalaria eram lidas por pessoas de diferentes classes sociais, uns revelando apreço e outros, profunda rejeição.

No corpus analisado verificou-se que o adaptador se mostrou atento a essas questões, considerando tanto as convenções do gênero e do estilo da época, como aos fatores contextuais em que seu público-leitor está inserido. Assim, buscou manter o equilíbrio em seus procedimentos, ora preservando aspectos intrínsecos à essência da obra fonte e ora atualizando o que se tornou ininteligível em termos linguísticos e culturais ao jovem leitor. 


\section{Dom Quixote de La Mancha, by Miguel de Cervantes, for young readers}

\begin{abstract}
This article discusses the adapted translation of The Ingenious Gentleman Don Quixote of La Mancha by Miguel de Cervantes, performed by Gullar. The study focuses on the analysis of the strategies used by the adaptor to make the classic Cervantes work more accessible to the young reader. Thus, it was essential that the theoretical aesthetic adaptation, contributed by Hans Robert Jauss (1994), to be received as the text mode in study set up with an explicit form of reception. To understand how the adaptor handles the text, in order to realize its reception, it was necessary to examine the studies by Regina Zilberman (1987) to present the four corners of the adaptation proposed by Göte Klimberg. Studies by BA Diogenes de Carvalho (2006), Mario F B. Monteiro (2010), and Lauro Amorim (2005) were also crucial in pointing out the importance of a theory of adaptation.
\end{abstract}

Keywords: Literary adaptation. Don Quixote. Reception Aesthetics

\section{Notas}

1 Comentário extraído de artigo escrito por Ferreira Gullar, intitulado Quixote, um maluco beleza, de 6 mar. 2005. Disponível em: <http:// www1.folha.oul.com.br>. Acesso em: 6 set. 2014.

2 Fundamenta-se, antes de tudo, no feito de que a primeira já havia sido publicada. Dessa forma, o conjunto fica perfeitamente homogeneizado e, assustadoramente, Alonso Quijano o Bom, acaba morrendo no fim (Tradução nossa).

3 O sentido paródico aqui empregado está baseado no conceito de paródia usado por Bóriev, quando diz que "A paródia consiste num exagero cômico na imitação, numa reprodução exageradamente irônica das peculiaridades características individuais de forma deste ou daquele fenômeno que revela sua comicidade e reduz seu conteúdo." (PROPP, 1992, p. 84).

4 Según Demetrio Estébanez (1996, p. 573) en la crítica literaria española, la expresión novela corta se utiliza para hacer referencia a una clase de relato que en estructura narrativa y en extensión se diferencia del cuento y de la novela extensa. Procedente del término italiano "novella", en su incorporación al español, mantuvo en su inicio el sentido dado en su lengua de origen: relato breve, en relación con la narración larga conocida como "romanzo" ("roman" en francés), término no presente en el español.

5 Foram identificados alguns traços característicos que as ajustam e as diferenciam: os heróis, cenários e a composição das novelas curtas são fantásticos ou idealistas, com pouca relação com a realidade. (tradução nossa)

6 Empregado com base no conceito de Vladimir Propp (1992, p. 152): "O humor é aquela disposição de espírito que em nossas relações com os outros, pela manifestação exterior de pequenos defeitos, nos deixa entrever uma natureza internamente positiva".

7 "Novela pastoril - principales características del género es la perfecta adecuación de todos estos elementos. El paisaje, las figuras humanas y su elevado concepto de amor responden a una misma visión idealista, del mismo modo que la acción y hasta el ritmo de la prosa ofrecen una apacible longitud que armoniza perfectamente con la quietud del ambiente descrito" (LÓPEZ, 1979, p. 242).

8 Conforme informações contidas nos dados técnicos exposto na mesma página da ficha catalográfica da adaptação em análise. 


\section{Referências}

AMORIM, Lauro Maia. Tradução e adaptação: Encruzilhadas da textualidade em Alice no País das Maravilhas, de Lewis Carrol, e Kim, de Rudyard Kipling. São Paulo: Unesp, 2005.

ARROYO, Feliciano Sevilla. In: CERVANTES, Miguel. Don Quijote de la Mancha. Barcelona: Debolsillo, 2013.

AZEVEDO, Paulo Seben de. O Uruguai de Basílio da Gama. Novo Hamburgo: Feevale Editora, 2001.

BERGSON, Henri. O riso: ensaio sobre a significação do cômico. Tradução Nthanael C. Caixeiro. Rio de Janeiro: Zahar, 1980.

CARVALHO, D. B. A. de. Adaptação literária para crianças e jovens: Robinson Crusoé no Brasil. 2006. 539 p. Tese (Doutorado em Letras) - Faculdade de Letras, PUCRS, Porto Alegre, 2006.

CERVANTES, Miguel. Don Quijote de la Mancha. Barcelona: Debolsillo, 2013.

. Dom Quixote de La Mancha. 4. ed. Tradução Ferreira Gullar. Rio de Janeiro: Revan, 2005.

COELHO, Nelly Novaes. Literatura infantil. São Paulo: Ática, 1993.

ECO, Umberto. Interpretação e superinterpretação. São Paulo: Martins Fontes, 1993.

ESTÉBANEZ CALDERÓN, Demetrio. Dicionário de términos literários. Madrid: Alianza, 1996.

GONÇALO JUNIOR. Gustave Doré - Dom Quixote. São Paulo: Opera Graphica, 2005.

JAUSS, Hans Robert. A história da literatura como provocação à teoria literária. São Paulo: Ática, 1994.

LÓPEZ, José García. Historia de la literatura española. 5. ed. Salamanca: J. Vicens Vives, 1976.
MONTEIRO, Mario Feijó Borges. O prazer da leitura: como adaptação de clássicos ajuda a formar leitores. São Paulo: Ática, 2010.

OLIVEIRA, Maria Lilia Simões de. Um clássico e suas adaptações: Dom Quixote em diferentes linguagens. In: Leitura \& Prática. Ano 23, n. 45, set. Campinas: ALB; São Paulo: Editora Global, 2005.

PEREIRA, Nilce Maria. Alice no Brasil traduções, adaptações e ilustrações. 2003. 90 p. Dissertação (Mestrado em Letras) Universidade de São Paulo, São Paulo, 2006.

PRADO, Amaya Obata Mouriño de Almeida. Adaptação, uma leitura possível: um estudo de Dom Quixote das crianças, de Monteiro Lobato. Santa Maria: UFSM/CPTL, 2008. Disponível em: <http://alb.com.br/arquivo-mort/edicoes_anteriores/anais16/sem08pdf/ sm08ss10_07.pdf>. Acesso em: 8 out. 2014.

PROPP, Vladimir. Comicidade e riso. Tradução Aurora Fornoni Bernardini e Homero Freitas de Andrade. São Paulo: Ática, 1992.

RAMOS, Flávia Brocchetto; PANOZZO, Neiva Senaide Petry. Acesso à embalagem do livro infantil. Perspectiva, Florianópolis, v. 23, n. 1, p. $115-130,2005$

VIEIRA, Maria A. da Costa. A recepção crítica do Quixote no Brasil. In:

(Org.). Dom Quixote: a letra e os caminhos. São Paulo: Universidade de São Paulo, 2006. p. 341-351.

ZILBERMAN, Regina. Estética da recepção e história da literatura. São Paulo: Ática, 1989. 